\title{
ETHNOGRAPHIES ON WEDDING CEREMONIES IN UZBEK LANGUAGE
}

\author{
Gulbahor Komilova
}

Department Of Linguistics: English Language 2nd Course Student Of Master's Degree, Fergana State University, Uzbekistan

\section{ABSTRACT}

Ethnographies are core example of national exoticism. They can also be called exotic vocabulary. The Uzbek language is rich in ethnography. This is due to the fact that they live in different areas and have cultural ties with different people. As globalization intensifies, people who seek to preserve the language, customs, and culture of their minority and pay special attention to ethnography and ethnolinguistics.

KEYWORDS: - Ethnography, ethnology, ethnoculture, wedding names, customs, exotics, exotic vocabulary.

\section{INTRODUCTION}

It is known that ethnolinguistics is a branch of linguistics that organizes the relationship and relationship between the people (nation, people) and its language on the basis of ethnolinguistics (the principle of common ethnic culture and ethnic language). It works mainly in two directions:

- To organize the ethnolinguistic features of the people on a descriptive basis;

- To organize the ethnolinguistic character of the people on a recommendatory basis.

The first goal can be conditionally called an external goal and the second an internal goal.

The relationship between language and ethnicity is a process in which their interaction takes place at two ages:

the influence of ethnic factors (customs, traditions, philosophical, religious views, etc.) on language development;

the influence of the linguistic factor on the development of ethnos (and ethnic character).

For example, in a nation, ethnicity (tradition, tradition, philosophical, religious views) is forgotten, and accordingly, the language units that express them also emerge from the active linguistic treasury and become a reality of the sixties. As a result, the minority of the nation / people / ethnic group begins to deteriorate. The nation / people / people will be deprived of a little spirituality. This, inevitably, is less reflected in the active lexicon. In the language lexicon, the ethnographic microsystem begins to decline. This is the influence of ethnic factors on language.

The first goal is to work on a more descriptive 
CURRENT RESEARCH JOURNAL OF PHILOLOGICAL SCIENCES 2(11):

104-106, November 2021

DOI: https://doi.org/10.37547/philological-crjps-02-11-23

ISSN 2767-3758

(C)2021 Master Journals

Crossref do

gil Google

Accepted $25^{\text {th }}$ November, 2021 \& Published $30^{\text {th }}$ November, 2021

research methodology. The branches of linguistics, such as ethnic nomenclature (onomastics), areal (territorial) linguistics, linguistic geography, dialectology (dialectology), history of language, sociolinguistics, cartography, use the scientific results obtained in this descriptive method of ethnolinguistics.

The study of ethnography in Uzbek linguistics began mainly in the 70s and 80s of the XX century. In the former Soviet Union, the lack of attention to folk customs and their assessment as obsolete also limited the scope of scientific research on this issue. The first research work in this area was carried out by A. Joraboyev and Z. Husainova. In the study, A. Joraboyev pointed out the existence of various traditions of our people and their names in our language, as well as the theoretical and practical significance of their organization. In addition, ethnographies, which are expressions of tradition, are widely organized in the works of researchers such as Sh. Nurullayeva, Y. Bobojonov in the methods of formal research. M. Qahhorova systematically studied ethnographies on the basis of language speech. The scientific researches of M. I. Byatushgova and A. K. Apoyev also made a great contribution to the study of ethnography in Turkish linguistics. The study of ethnographic monographs provides a convenient opportunity to reveal the interrelationships of linguistic units, to organize them as a field. It is of little importance to combine the names of concepts related to rituals in the Uzbek language on a systematic basis with the need for a special organ, to combine the concepts associated with different customs and rituals into a specific micro-field and semantically analyze them.

The internal structure of ethnographies and the discovery of various relationships between structural units are also of great importance for modern Uzbek linguistics. The above works are organized ethnographies of Uzbek traditions existing in the territory of Uzbekistan. The Uzbek people of northern Afghanistan also have common and unique ethnographies with Uzbekistan, which are also the common wealth of the Uzbek nation. Cultural and social ties between the two regions have always been active. In fact, the customs of two peoples living in the same area, belonging to the same people, are more general, in part less specific. These similarities and differences can also be observed in the example of wedding ceremony ethnographies. The emphasis is on the ethnographic lexicon being very broad in terms of subject matter and volume. Ethnographies of wedding ceremonies require a separate organ. $H$. Ismoilov, who organizes Uzbek weddings, divides Uzbek weddings into the following spiritual groups:

- weddings associated with an important date (birthday wedding, "beshik to'yi" ${ }^{1}$,.);

- circumcision ceremonies; youth weddings ("yigitlik oshi" ${ }^{2}$ );

- wedding ("qiz ko'rdi" 3 , "non sindirish" ${ }^{4}$,);

- ceremonies with the wedding ("qiz oshi");

- after wedding ceremonies.

\section{Conclusion}

In conclusion, it can be said that the micro-field of weddings and mournings plays an important role in ethnography. The fact that the lexical units belonging to this micro-area differ from the same micro-field units in the fraternal peoples, the interdialectal peculiarities of the Uzbek language will be considered in our next works.

\footnotetext{
${ }^{1}$ Ceremony held after the birth of a baby

${ }^{2}$ A party that the boys organize when they reach puberty

${ }^{3}$ One of the ceremonies held on the wedding day

${ }^{4}$ A tradition that is a sign of engagement for Uzbek people
} 
CURRENT RESEARCH JOURNAL OF PHILOLOGICAL SCIENCES 2(11):

104-106, November 2021

DOI: https://doi.org/10.37547/philological-crjps-02-11-23

ISSN 2767-3758

(C)2021 Master Journals

crossref do) 8: Google

Accepted25 $5^{\text {th }}$ November, 2021 \& Published $30^{\text {th }}$ November, 2021

\section{REFERENCES}

1. Bobojonov Y. Ethnographic lexicon of South Khorezm: Candidate of Philological Sciences ... diss. Tashkent, 1997.

2. Joraboev I. Names of weddings in Uzbek language. Tashkent: Fan, 1971.

3. Mahmud Halim Bright. Uzbek language phraseologic dictionary Afghanistan 2006.

4. Usmanova, S. R., \& Ismatullayeva, N. R. (2020). Expression Of Lacunas In Comparative Study of Kinship Terms In Chinese And Uzbek Languages. Solid State Technology, 63(6), 4974-4985.

5. Olim Kohkan. The Uzbek language in Afghanistan and its current state // www.turonzamin.org. June 10, 2013. 